\title{
Blinde vinkler. Billeder af kolonien Dansk Vestindien
}

\author{
Tale ved åbning af udstillingen 18. maj 2017
}

af Mette Kia Krabbe Meyer, Sarah Giersing og Mathias Danbolt

\section{$\mathrm{L}$}

andskabet ligger åbent og udstrakt for blikket. Markerne er et puslespil af brunt og grønt. Med tæt bevoksning hist og her. Nede i bugten ligger en by - på havet en række skibe. Frederiksted, marts 1834 står der, og det er nemt at føle sig hensat til en bakketop i den danske koloni først i 1800-tallet. Der er en lethed i det lyse landskab og den svagt overskyede, men klare himmel set oppefra.

Illusionen virker. Vi har en fornemmelse af, at vi ser ind $i$ en anden tid. Men samtidig gør billedet, for det er jo det, det er, os opmærksom på, at det er billede og ikke vindue til fortiden. For forrest sidder en mand. Han er stået af sin hest og har sat sig på jorden med sin blok. Han tegner et landskab, sikkert det landskab vi ser på, ja måske har kunstneren Frederik von Scholten lavet et selvportræt, og under alle omstændigheder har han med den lille skikkelse i den blå frakke lukket vinduet og peget på, at her har vi et landskabsbillede.

I Blinde vinkler. Billeder afkolonien Dansk Vestindien gør vi kuratorer det samme. Det vil sige, vi ser på billeder som billeder. Ikke blot tegninger, men også tidlige træsnit og kobberstik, atlas og landkort, litografier, oliemalerier og fotografier, der forestiller den tidligere danske koloni. Historiske billeder, men også nutidens rejsereklamer, computerspil og samtidskunstværker. Vi fortæller om

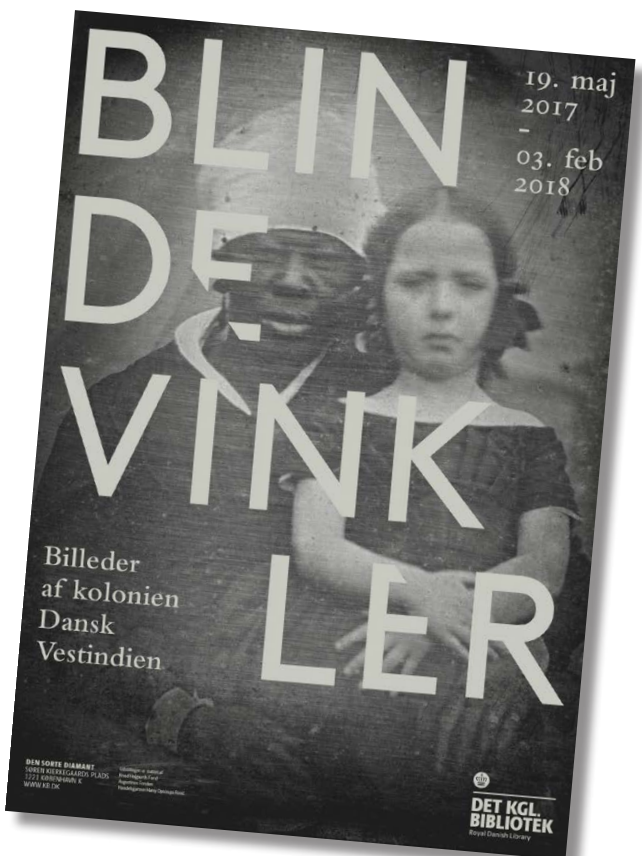

tegnerne, malerne, fotograferne, kunstnerne og nogle gange om deres meninger og intentioner. Men også om billedernes funktioner i litteratur, administration, turisme og meget andet.

Von Scholtens tegning er typisk for de såkaldte pittoreske landskabsmalerier, der blev populære i Europa i sidste del af 1700-tallet. Det fremhæver skønheden i naturen, her ikke i en vild natur, men i det tæmmede landskab. Det er en romantisk skildring, som ikke fortæller om, at Danmark som andre kolonimagter indførte slaveri. At den danske velstand på øerne blev skabt af slavegjorte afrikanere udsat 


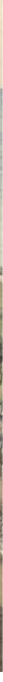

Frederik von Scholten: Frederikssted. Farvelagt tegning, 1837. M/S Søfart.

for vold og undertrykkelse. Det er den hvide/danske kunstners blik, vi ser med. Kun når man ser rigtig godt efter får man øje på de små markarbejdere, der høster sukkerrør.

Det er gennemgående for hele udstillingen, at de historiske billeder, vi har fundet $\mathrm{i}$ vores og andre institutioners arkiver, er skabt af kolonialisterne, og at billederne har deres perspektiv. Den slavegjorte afrocaribiske befolkning er ofte udeladt eller, senere efter slaveriets ophævelse, iscenesat af danskerne. Det gælder ikke blot von Scholtens tegninger, men også familiealbum med danske familier og deres sorte tjenestefolk, amatørfotograferne og de professionelles optagelser, som man kan se i udstillingen.

Det har rørt os at opleve, i hvor høj grad det at skabe billeder og i hvert fald at arkivere har været et hvidt privilegium. Og det har været en vigtig drivkraft i vores arbejde med udstillingen. At synliggøre kolonialisternes perspektiv og at undersøge de blinde vinkler. At finde ud af, hvad man har malet, tegnet, fotograferet, og hvad man ikke har. At forstå, hvilke billeder, der er blevet arkiveret. Og hvordan de kan understøtte bestemte opfattelser af virkeligheden. 
I Jeannette Ehlers' videoperformance Whip it Good, udsættes et hvidt lærred for en af de mest ikoniske afstraffelsesmetoder under slaveriet: pisken. Scenen finder sted i det Vestindiske Pakhus, der blev bygget som lager for varer fra de caribiske kolonier, og som i dag huser Den Kongelige Afstøbningssamlings gipskopier af den hvide europæiske kunsthistorie. Midt i dette rum smelter kolonihistorien og kunsthistorien ind $\mathrm{i}$ hinanden. Et kunstværk tager form som en afstraffelse. En afstraffelse skaber et kunstværk. Når vi i vores udstilling viser Whip it Good er det unægtelig med til at minde om den vold, de slavegjorte blev udsat for i den danske koloni. Men det er et hvidt lærred, der piskes her. Hvad den hvide flade repræsenterer, står åbent. Er det ideen om dansk uskyld? Hvidvaskningen af historien? Den komfortable kollektive glemsel?

For os repræsenterer Whip it Good et hårdtslående forsøg på at piske noget nyt ind $\mathrm{i}$ historien og i nutiden, noget der er blevet ignoreret, overset, marginaliseret. Og for os var mødet med dette værk tilbage i 2013 med til for alvor at piske os i gang med at arbejde grundigere med, hvorledes den danske kolonihistorie er blevet behandlet i dansk kunsthistorieskrivning - eller, snarere, netop ikke er blevet behandlet. Indenfor historiefaget har kolonihistorien længe været på dagsordenen, men man har nemt kunnet studere kunsthistorie i Danmark uden at møde kolonihistorien og dennes betydning i en nordisk kontekst - økonomisk, kulturhistorisk såvel som æstetisk. Når vi har spurgt museer og andre institutioner om værker, der knytter sig til den danske kolonihistorie, er vi tit blevet mødt med det svar, at slaveri- og kolonihistorien jo "ikke var kunstnernes motiv" i Danmark, og at der derfor ikke rigtig er noget at komme efter $\mathrm{i}$ arkiverne. I løbet af de sidste ti år har arbejder af kunstnere som Jeannette Ehlers, Nanna Debois Buhl og La Vaughn Belle bidraget til at udfordre denne ide om, at kolonihistorien ikke har sat visuelle aftryk i kunsthistorien. Deres værker har været med til at få både museumsfolk og kunsthistorikere som os til at vende tilbage til arkiverne og se den danske billedhistorie med nye øjne.

Effekten af Jeannette Ehlers, Nanna Debois Buhl og La Vaughn Belles engagement har været mærkbar i de forskellige udstillinger, der er åbnet i Danmark i forbindelse med 100 års-markeringen af overdragelsen af den tidligere koloni Dansk Vestindien til USA, hvor kunst og visuel kultur står centralt. Vi håber denne kritiske interesse for kolonialismens æstetiske kultur lever videre også efter 2017, for der er meget arbejde forude. I Blinde vinkler præsenterer vi blot et lille udvalg af det store visuelle materiale, der knytter sig til den caribiske koloni. Og der er stof nok til mange flere udstillinger både om Dansk Vestindien og om de andre tidligere danske koloniale territorier. $\mathrm{Vi}$ håber, at vores udstilling kan bidrage til at få endnu flere til at interessere sig for og diskutere den rolle billeder har haft i kolonihistorien - og for vores forståelse af den. 


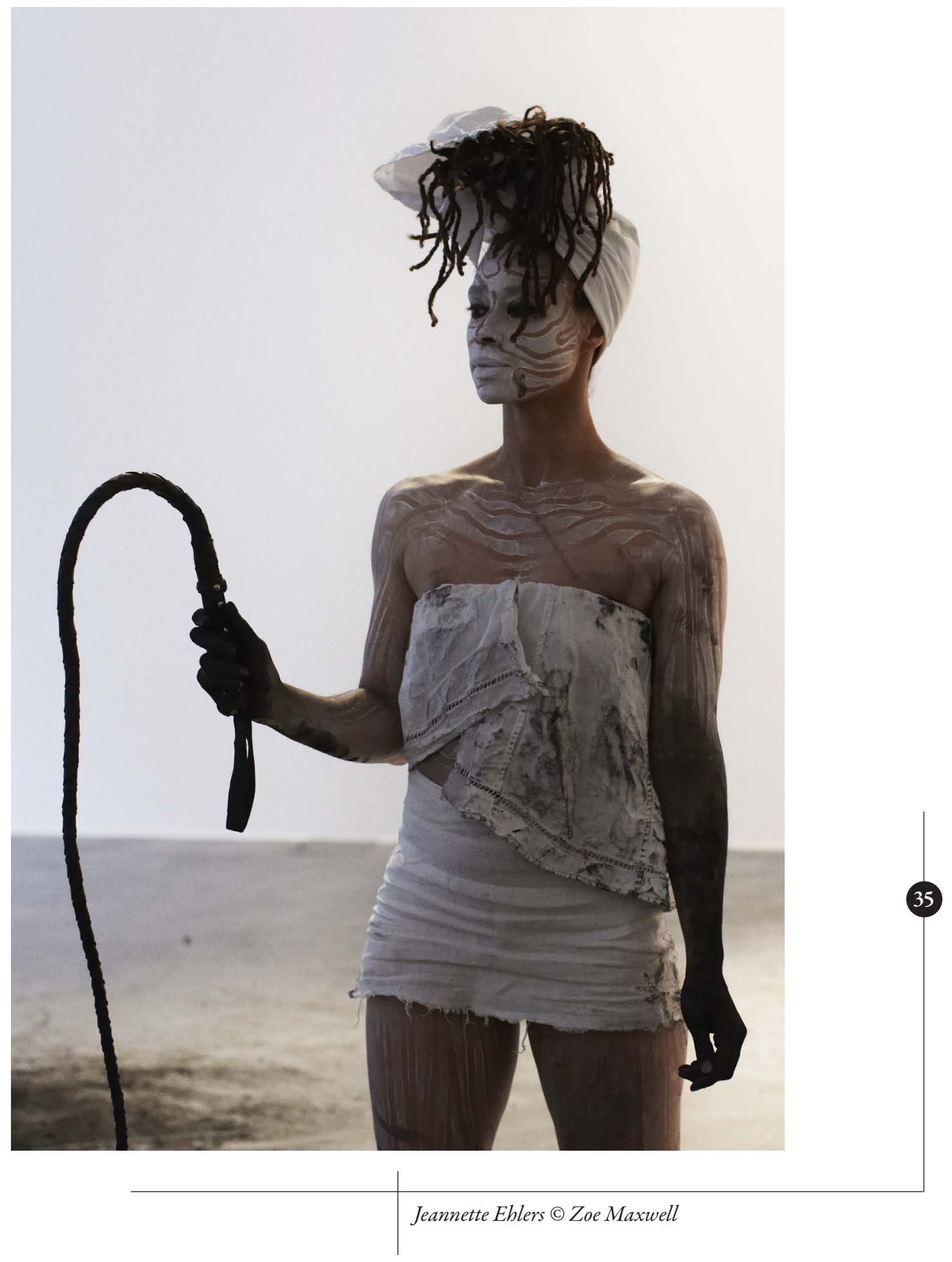


"It's like zooming in on a

flower in a war zone... Or something like that."

S ådan siger en kvinde om det idylliske landskabsbillede af Frederik von Scholten. Så bryder en mandestemme ind: "It's like... A trauma is turned into pleasure." De to er i færd med at sætte ord på, hvordan billedet virker på dem.

Vi er vant til, at en udstilling taler med én stemme. En udstilling præsenterer som regel genstande ledsaget af tekster, hvor afsenderen er anonym. Sproget er poleret og præcist, og det kan skabe en slags upersonlig autoritet. Tekst lyver let på den måde. Lyden af en stemme, derimod, kan aldrig fortrænge, at det er en bestemt person, der taler. Klangen kan røbe følelser. Tøven. Tvivl.

I Blinde vinkler kan man høre mange stemmer. Vi har valgt at lade vores kuratoriske fortælling, som er formidlet i det tilhørende hæfte, blive afbrudt af lydspor med titlen: "What Lies Unspoken". Det er korte lydcollager, der er sat sammen af optagelser med forskellige mennesker, der reagerer på udstillingens billeder.

Det er Temi Odumosu, der har været drivkraften bag "What Lies Unspoken". Vi lærte Temi at kende, da hun som forsker besøgte vores arkiver og gjorde os opmærksom på, at de rummer så meget mere, end vi først havde troet. At der var stumme stemmer nede i kuverterne. Hun viste os også - med sit arbejde for Living Archives - at en udstilling kan være med til at bryde den stilhed, der alt for ofte omgærder de smertefulde dele af historien. Tak til Temi for at anspore os.
Gennem snart to år har vi talt med en lang række mennesker om billederne af Dansk Vestindien. Vi vil gerne takke alle, der har deltaget i de forskningsnetværk, vi har været del af og alle på udstillingsholdet, lige fra produktionsledere til praktikanter. I stillede kritiske spørgsmål og pegede på vores blinde vinkler, men I opmuntrede og inspirerede os også. Og I viste os, hvor forskelligt vi kan se på den samme fortid, selv inden for det snævre felt af fagnørder.

De manges gavmilde deltagelse $\mathrm{i}$ samtalen - og for nogle enkeltes vedkommende også deres lige så sigende ønske om at lukke samtalen ned - har været med til at forme vores udstilling. Vi kan ikke takke alle her, men her vil vi alligevel fremhæve nogle samarbejdspartnere, hvis bidrag man vil se i udstillingen.

\section{$\neg$ ak til Helle Stenum for at lade os vise et klip fra filmen "Vi bærer det i os". Tak til Anna Neye, til} Peder Hornshøj, til Astrid Nonbo Andersen og til Eske Knudsen for medvirke i de samtaler, der er udstillingens Efterbilleder. Tak til Henrik Holm og resten af Statens Museum for Kunst for at sige JA til at lave "What Lies Unspoken" med os, selvom vi henvendte os meget sent!

Og sidst men ikke mindst: Tak til kunstnerne La Vaughn Belle, Nanna Debois Buhl og Jeannette Ehlers for at stille deres værker til rådighed. Og for at stole på, at den sammenhæng vi har valgt at præsentere dem $i$, kan bringe nye fortællinger frem - både i deres værker og i de historiske billeder, de deler rummet med. 


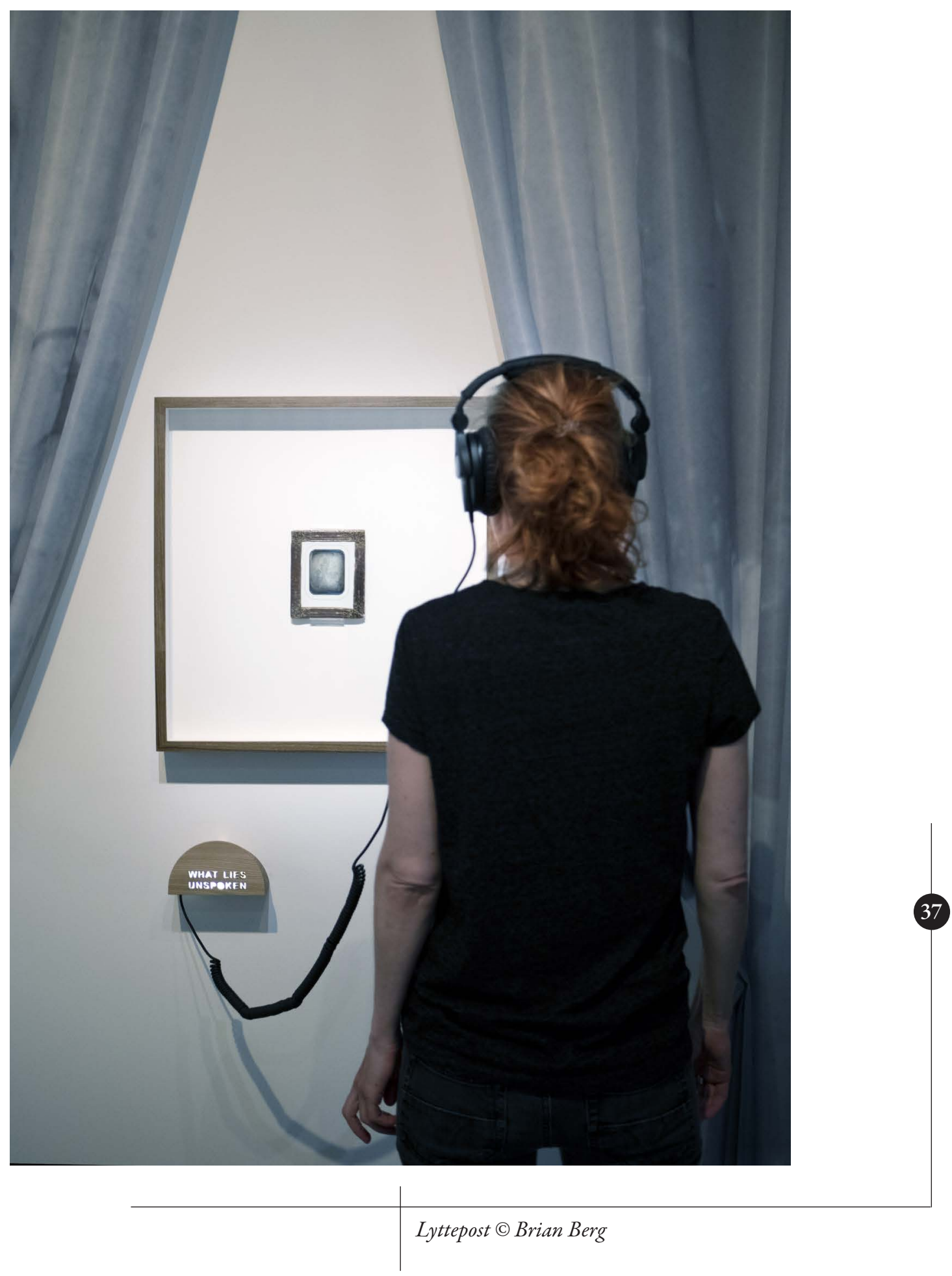

